Article

\title{
Unveiling the decomposition mechanism of formic acid on Pd/WC(0001) surface by using density function theory
}

\author{
Jinhua Zhang a,b, Yuanbin She ${ }^{a, *}$ \\ a College of Chemical Engineering, Zhejiang University of Technology, Hangzhou 310014, Zhejiang, China \\ ${ }^{\mathrm{b}}$ School of Materials and Environmental Engineering, Chizhou University, Chizhou 247000, Anhui, China
}

\section{A R T I C L E I N F O}

\section{Article history:}

Received 18 June 2019

Accepted 26 July 2019

Published 5 March 2020

\section{Keywords:}

Density functional theory

Formic acid

Direct formic acid fuel cells WC(0001)-supported Pd monolayer

Decomposition mechanism

\begin{abstract}
A B S T R A C T
In pursuit of low-cost direct formic acid fuel cells, tungsten carbide (WC) supported Pd catalyst is considered as an ideal candidate for efficient decomposition of formic acid due to low Pd utilization and excellent performance. Herein, different adsorption configurations and active sites of the intermediates, involved in the $\mathrm{HCOOH}$ decomposition, on WC(0001)-supported Pd monolayer (Pd/WC(0001)) surface investigated by using density functional theory. The results reveal that trans- $\mathrm{HCOOH}, \mathrm{HCOO}$, cis- $\mathrm{COOH}$, trans- $\mathrm{COOH}, \mathrm{HCO}, \mathrm{CO}, \mathrm{H}_{2} \mathrm{O}, \mathrm{OH}$ and $\mathrm{H}$ exhibit chemisorption on $\mathrm{Pd} / \mathrm{WC}(0001)$ surface, whereas cis- $\mathrm{HCOOH}$ and $\mathrm{CO}_{2}$ exhibit weak interactions with $\mathrm{Pd} / \mathrm{WC}(0001)$ surface. In addition, the minimum energy pathways of $\mathrm{HCOOH}$ decomposition are analyzed to generate $\mathrm{CO}$ and $\mathrm{CO}_{2}$ due to the fracture of $\mathrm{C}-\mathrm{H}, \mathrm{H}-\mathrm{O}$ and $\mathrm{C}-\mathrm{O}$ bonds. The adsorbed $\mathrm{HCOOH}, \mathrm{HCOO}$, $\mathrm{mHCOO}$, cis- $\mathrm{COOH}$ and trans- $\mathrm{COOH}$ configurations exhibit dissociation rather than desorption. $\mathrm{CO}$ formation occurs through the decomposition of cis- $\mathrm{COOH}$, trans- $\mathrm{COOH}$ and $\mathrm{HCO}$, whereas the $\mathrm{CO}_{2}$ formation happens due to the decomposition of HCOO. It is found that the most favorable pathway for $\mathrm{HCOOH}$ decomposition on $\mathrm{Pd} / \mathrm{WC}(0001)$ surface is $\mathrm{HCOOH} \rightarrow \mathrm{HCOO} \rightarrow \mathrm{CO}_{2}$, where the formation of $\mathrm{CO}_{2}$ from $\mathrm{HCOO}$ dehydrogenation determines the reaction rate. Overall, $\mathrm{CO}_{2}$ is the most dominant product of $\mathrm{HCOOH}$ decomposition on $\mathrm{Pd} / \mathrm{WC}(0001)$ surface. The presence of $\mathrm{WC}$, as monolayer Pd carrier, does not alter the catalytic behavior of Pd and significantly reduces the Pd utilization.
\end{abstract}

(C) 2020, Dalian Institute of Chemical Physics, Chinese Academy of Sciences. Published by Elsevier B.V. All rights reserved.

\section{Introduction}

As an alternative power source for portable electronic devices, direct formic acid fuel cell (DFAFC) has garnered significant interest due to its distinct advantages, such as limited fuel crossover, high electromotive force, non-toxicity of formic acid, and high practical power density at low temperature [1,2]. Furthermore, an increasing number of theoretical and experimental studies has focused on the decomposition of $\mathrm{HCOOH}$ to probe catalyst activity, intermediates, and possible reaction mechanism [3-23].

For instance, platinum (Pt), palladium (Pd) are widely studied electrocatalysts for $\mathrm{HCOOH}$ oxidation. Hence, these metals are utilized as the anode material in DFAFCs, where the decomposition of $\mathrm{HCOOH}$ [17-26] produces $\mathrm{CO}$ or $\mathrm{CO}_{2}$. Both $\mathrm{Pd}$ and Pt belong to the same group of the periodic table and possess similar electronic structure, leading to similar electrocatalytic behavior. However, the lower-price and excellent anti-poisoning performance of $\mathrm{Pd}$ make it a promising anode candidate in DFAFCs. Moreover, recent studies have demonstrated

\footnotetext{
* Corresponding author. Tel/Fax: +86-571-88320533; E-mail: sheyb@zjut.edu.cn

This work was supported by the National Natural Science Foundation of China (21776259) and Key Laboratory of Micro-Nano Powder and Advanced Energy Materials of Anhui Higher Education Institutes, Chizhou University.

DOI: S1872-2067(19)63463-7 | http://www.sciencedirect.com/science/journal/18722067 | Chin. J. Catal., Vol. 41, No. 3, March 2020
} 
that the electrocatalytic performance of Pd for $\mathrm{HCOOH}$ oxidation is superior to Pt [27-30]. Therefore, Pd-based catalytic electrodes are considered as ideal substitutes for Pt-based catalytic materials.

However, the limited reserves of Pd in earth crust hinders the widespread utilization of Pd as an electrocatalyst for formic acid oxidation in DFAFCs. The large-scale commercial utilization of Pd-based catalysts can be realized by reducing the amount of precious metals and increasing the catalytic activity of Pd-based nanocomposite.

In general, the catalytic performance is influenced by the composition, structure and carrier of the catalyst material. The most commonly used carriers are activated carbon (AC), graphite, and carbon nanotubes (CNTs), however, these materials exhibit poor stability due to low $\mathrm{pH}$, high humidity, high oxygen concentration, and high potential. On the other hand, the transition metal tungsten carbide renders excellent electrical conductivity and electrochemical stability. In 1973, Levy et al. [31] had reported that the surface electronic properties carbon-modified WC resemble Pt. Therefore, WC exhibits Pt-like catalysis behavior, which makes it an interesting catalyst carrier for fuel cell applications [32-35].

Since the catalytic reaction mainly occurs on the catalyst surface, gold $(\mathrm{Au}), \mathrm{Pt}$ and $\mathrm{Pd}$ monolayer catalysts have attracted extensive attention. Furthermore, WC-supported monolayer $\mathrm{Au}$ [36], Pt [37] and Pd [38,39] are usually used as low-cost electrocatalysts for electrode reactions. For instance, Zhang et al. [40] have investigated the kinetics of oxygen reduction reaction(ORR) on the WC(0001) supported monolayer Au, Pd, and Pt catalysts, where WC supported Pd nanoparticles have rendered superior stability and high activity in alkaline electrolytes, which are comparable to Pt-based catalysts [39].

The close attachment of the WC nanocrystal with the Pd nanoparticles suggests a strong interaction between the WC and Pd by the elemental mapping analysis, the HRTEM and HAADF-STEM analysis, which is expected to produce synergistic effects between WC and Pd for enhanced catalytic activity [41].

Xin's group [42] reported that the $3 d_{5 / 2}$ binding energies of Pd species showed a shift from $336.0 \mathrm{eV}$ for Pd/C to $336.13 \mathrm{eV}$ for Pd/WC-C as a result of modification by WC by X-ray photoelectron spectroscopy (XPS), which exhibited the metal-support interactions between Pd and WC. The better catalytic activity for the FAEO was observed on the Pd/WC-C catalyst, which was 2.5 times higher than that of the $\mathrm{Pd} / \mathrm{C}$ catalyst on the basis of the specific surface area of the catalysts. A slower current decay was observed on the WC supported catalysts, compared with that on the carbon supported catalysts. This result revealed the synergistic interactions of Pd and WC catalysts, leading to both stabilization and promotion of the catalytic activity for the FAEO.

The oxidation of formic acid generally follows a dual path mechanism, which can be divided into a direct path and an indirect path. In the direct path, $\mathrm{CO}_{2}$ is generated by fracturing the $\mathrm{O}-\mathrm{H}$ and $\mathrm{C}-\mathrm{H}$ bonds, whereas, in the indirect path, $\mathrm{CO}$ is generated by breaking the $\mathrm{C}-\mathrm{O}$ and $\mathrm{C}-\mathrm{H}$ bonds, Then, the resulting $\mathrm{CO}$ is further oxidized to $\mathrm{CO}_{2}$. Tao et al. [41] have in- vested that the chronopotentiometric curves of formic acid oxidation on $\mathrm{Pd}-\mathrm{WC}_{\mathrm{P}} / \mathrm{Graphene}$ is smooth, confirming formic acid oxidation on $\mathrm{Pd}-\mathrm{W} \mathrm{C}_{\mathrm{P}} / \mathrm{Graphene}$ with no obvious poisonous species CO on the surface . Guo et al. [43] have experimentally studied that the catalytic influence of WC-supported Pd catalyst on formic acid oxidation and demonstrated the direct dehydrogenation path of formic acid oxidation. However, the detailed reaction mechanism is still unclear. Herein, we aimed to explore the detailed reaction of direct and indirect pathways of formic acid oxidation on Pd/WC(0001) surface by using the first principle calculations. The adsorption of different intermediate species and the decomposition mechanism of $\mathrm{HCOOH}$ have been investigated on $\mathrm{Pd} / \mathrm{WC}(0001)$ surface and results are compared with $\mathrm{Pd}(111)$ surface. The decomposition mechanism of formic acid on Pd/WC(0001) is consistent with that on Pd clusters. Formic acid prefers to decompose through dehydrogenation rather than dehydrate on both Pd/WC(0001) surface and $\mathrm{Pd} 7$ cluster, and $\mathrm{CO}_{2}$ would be the main product [44].

\section{Experimental}

\subsection{Computational methods}

In this paper, program package DMol3 [45] of Materials Studio was utilized to perform the spin-unrestricted density functional theory (DFT) calculations. The generalized gradient approximation, with Perdew-Burke-Ernzerhof functional (GGA-PBE) [46], was used to describe the electron exchange and correlation. GGA-PBE method is widely used in DFT calculations of catalytic materials and their adsorbates [47-50]. A double-numerical basis with polarization functions (DNP) is utilized to expand the valence electron functions into a set of numerical atomic orbitals. The core treatment is set with density functional semicore pseudopotential (DSPP) and the real-space global orbital cutoff radius was set at $4.9 \AA$ to improve the accuracy and efficiency of DFT calculations. The convergence standard for geometric optimizations and energy calculations was set to the tolerance for SCF, energy, maximum force, and maximum displacement of $1.0 \times 10^{-6} \mathrm{Ha}, 1.0 \times 10^{-5}$ Ha, $0.002 \mathrm{Ha} / \AA$, and $0.005 \AA$, respectively.

The transition states (TS) were identified by using the complete LST/QST method of the elementary reactions [51]. The frequency analysis of the transition states was carried out, and only one imaginary frequency is validated by using eigenvalue, which followed the optimization method and assured the transition state.

\subsection{Surface models}

W-terminated WC(0001) exhibits excellent stability and activity, importantly, the presence of $\mathrm{Pd}$ monolayer on W-terminated WC(0001) demonstrates better energy efficient than the C-terminated WC(0001) surface [52]. Therefore, $\mathrm{W}$-terminated WC(0001) is chosen as the carrier of monolayer $\mathrm{Pd}$. Pd atoms were sequentially deposited on W-terminated WC(0001) to obtain a single layer structure, which simulates 
the surface of $\mathrm{Pd} / \mathrm{WC}(0001)$. The same method has been adopted in the previously published reported[40]. The Pd atoms firmly adhered to the hcp position of WC(0001) to the hcp position of WC (0001) on the top of $\mathrm{C}$ atoms.

Starting from the bulk WC structure, a $(3 \times 3)$ supercell model, with 9 atoms in each layer, was established to simulate the surface of Pd/WC(0001). The supercell was modeled by arranging periodically repeated slabs with 7 atomic layers, consisting of three WC bilayers and one Pd monolayer, and providing a vacuum region of $15 \AA$, which separated the periodically arranged slabs. Brillouin zone integration was performed on a $5 \times 5 \times 1$ grid, by using the Monkhorst-Pack $k$ points. DFT-D correction has been carried out for all calculations, and long-range Vander interactions has been considered. During the optimization process, the bottom four atomic layers were constrained to simulate bulk characteristics, whereas the remaining layers, including the subsequently deposited Pd monolayer and adsorbates, were allowed to relax freely.

\section{Results and discussion}

The surface energy ( $\left.E_{\mathrm{Pd}, \text { surf }}\right)$, adsorption energy ( $\left.E_{\mathrm{ads}}\right)$, total enthalpy change $(\Delta H)$, activation energy $\left(E_{\mathrm{b}}\right)$, electron density difference $(\Delta \rho)$ and co-adsorption energy ( $\left.E_{\text {coads }}\right)$ were calculated by using the following mathematical formula:

$$
E_{P d, \text { surf }}=1 / n\left(E_{P d / W C(0001)}-E_{W C(0001)}-n E_{P d, b u l k}\right)
$$

where $E_{\mathrm{Pd} / \mathrm{wC}(0001)}$ is the total energy of the slab, $E_{\mathrm{wc}(0001)}$ is the total energy of the substrate, $n$ is the number of $\mathrm{Pd}$ atoms, and $E_{\mathrm{Pd} \text {,bulk }}$ is the bulk energy per Pd atom obtained from an independent bulk calculation. If the surface energy is lower than zero, the dispersed Pd atoms on WC(0001) surface would be favoured. Conversely, if the surface energy is higher than 0 , the dispersed Pd atoms would prefer to accumulate to form clusters or particles.

$$
E_{\text {ads }}=E_{\text {adsorbate } / \mathrm{Pd} / \mathrm{WC}(0001)}-E_{\mathrm{Pd} / \mathrm{WC}(0001)}-E_{\text {adsorbate }}
$$

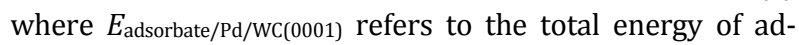
sorbate and Pd/WC(0001) system in the equilibrium state, $E_{\mathrm{Pd} / \mathrm{wc}(0001)}$ represents the total energy of an adsorbate-free Pd/WC(0001) surface, and Eadsorbate corresponds to the total energy of free adsorbates. Based on this definition, the negative values of adsorption energy correspond to the favorable and stable adsorption of $\mathrm{Pd} / \mathrm{WC}(0001)$.

$$
\Delta H=E_{\mathrm{FS}}-E_{\mathrm{IS}}
$$

where $E_{\mathrm{FS}}$ and $E_{\mathrm{IS}}$ represent the energies of final state (FS) and initial state (IS), respectively.

$$
E_{\mathrm{b}}=E_{\mathrm{TS}}-E_{\mathrm{IS}}
$$

where $E_{\mathrm{TS}}$ and $E_{\mathrm{IS}}$ represent the energies of the transition state (TS) and initial state (IS), respectively.

$$
\Delta \rho=\Delta \rho_{\text {adsorbate } / P d / W C(0001)}-\Delta \rho_{P d / W C(0001)}-\Delta \rho_{\text {adsorbate }}
$$

where $\Delta \rho$ represents the electron density difference, $\Delta \rho_{\text {adsorb- }}$ ate/Pd/WC(0001) refers to the total electron density of adsorbate and $\mathrm{Pd} / \mathrm{WC}(0001)$ system in the equilibrium state, $\Delta \rho_{P d / W C(0001)}$ denotes the total electron density of a clean Pd/WC(0001) surface, and $\Delta \rho_{\text {adsorbate }}$ corresponds to the total electron density of the free adsorbate.

$$
E_{\text {coads }}=E_{(\mathrm{A}+\mathrm{B}) / \mathrm{Pd} / \mathrm{WC}(0001)}-E_{\mathrm{Pd} / \mathrm{WC}(0001)}-E_{\mathrm{A}}-E_{\mathrm{B}}
$$

where $E_{\mathrm{A}}, E_{\mathrm{B}}, E_{\mathrm{Pd} / \mathrm{wC}(0001)}$ and $E_{(\mathrm{A}+\mathrm{B}) / \mathrm{Pd} / \mathrm{WC}(0001)}$ are represent the total energy for the correlative free molecule of $\mathrm{A}$ and $\mathrm{B}$, the $\mathrm{Pd} / \mathrm{WC}(0001)$ slab with a $(3 \times 3)$ supercell and the co-adsorbed $(A+B)$ and $\mathrm{Pd} / \mathrm{WC}(0001)$ slab systems, respectively.

\subsection{Evaluation of calculation method and model}

In the case of bulk WC, the calculated lattice parameters, $a=$ $b=2.906 \AA$, and $c=2.838 \AA$ are consistent with the experimental data ( $a=b=2.91 \AA \AA$ and $c=2.83 \AA$ ) [53].

The free formic acid in gaseous phase exhibits, both cis and trans configurations. The calculated energy of trans conformation is $0.142 \mathrm{eV}$ lower than the cis- $\mathrm{HCOOH}$, which is consistent with the experimental value of $0.17 \mathrm{eV}$ [54]. The calculated $\mathrm{C}-\mathrm{H}, \mathrm{C}=\mathrm{O}, \mathrm{C}-\mathrm{OH}$ and $\mathrm{O}-\mathrm{H}$ bond lengths in the trans-HCOOH configuration are 1.105 (1.097) $\AA$, 1.215 (1.202) $\AA$, 1.358 (1.343) $\AA$ and 0.983 (0.972) $\AA$, respectively. One should note that the as-calculated values are consistent with the previously reported experimental values, as displayed in the parentheses.

The calculated surface energy is $-1.06 \mathrm{eV}$ per atom, indicating that $\mathrm{Pd}$ atoms are favoured to be dispersed over W-terminated WC(0001) surface since the chemical bonds between the $\mathrm{W}$ atoms and $\mathrm{Pd}$ atoms are considerably strong. According to the calculated result, it can conclude that in reality WC(0001) supported monolayer Pd surfaces should commonly exist, which is in agreement with the result of Zhang's report [40].

\subsection{Intermediates adsorption on Pd/WC(0001) surface}

The adsorption energies were calculated for intermediates and the results are summarized in Table 1, Moreover, the most stable adsorption configuration and the corresponding key structural parameters of all intermediates at their favorable positions are also listed in Table 1 . The most stable structures of all intermediates, involving $\mathrm{HCOOH}$ adsorbed on $\mathrm{Pd} / \mathrm{WC}(0001)$ surface, are presented in Fig. 1. The electron density difference map exhibits the charge transfer between

\begin{tabular}{|c|c|c|c|c|}
\hline Species & $\begin{array}{l}\text { Adsorption } \\
\text { sites }\end{array}$ & Configurations & $\begin{array}{c}\text { Bond } \\
\text { length/Å }\end{array}$ & Eads/eV \\
\hline $\mathrm{HCOOH}$ & top & O-bound & $2.30(0-P d)$ & -0.87 \\
\hline cis-HCOOH & - & above surface & - & -0.42 \\
\hline HCOO & bridge & 0-bound & $2.18(\mathrm{O}-\mathrm{Pd})$ & -3.51 \\
\hline mHCOO & bridge & O-bound & $2.16(0-P d)$ & -2.56 \\
\hline cis- $\mathrm{COOH}$ & top & C-bound & $2.05(0-P d)$ & -2.68 \\
\hline trans- $\mathrm{COOH}$ & top & C-bound & $2.09(0-P d)$ & -2.57 \\
\hline $\mathrm{HCO}$ & bridge & C-bound & $2.04(\mathrm{C}-\mathrm{Pd})$ & -2.26 \\
\hline $\mathrm{CO}$ & fcc & C-bound & $2.21(\mathrm{C}-\mathrm{Pd})$ & -1.51 \\
\hline $\mathrm{H}_{2} \mathrm{O}$ & top & O-bound & $2.36(\mathrm{O}-\mathrm{Pd})$ & -0.60 \\
\hline $\mathrm{OH}$ & fcc & O-bound & $2.29(0-\mathrm{Pd})$ & -3.15 \\
\hline $\mathrm{CO}_{2}$ & - & above surface & - & -0.29 \\
\hline $\mathrm{H}$ & fcc & H-bound & $1.92(\mathrm{H}-\mathrm{Pd})$ & -2.67 \\
\hline
\end{tabular}
the intermediate, including formic acid and the Pd/WC(0001) surface(Fig. 1). The blue-colored portion indicates the gained

\section{Table 1}

Adsorption sites, adsorption energies and key structural parameters of different intermediates on Pd/WC(0001) surface. 


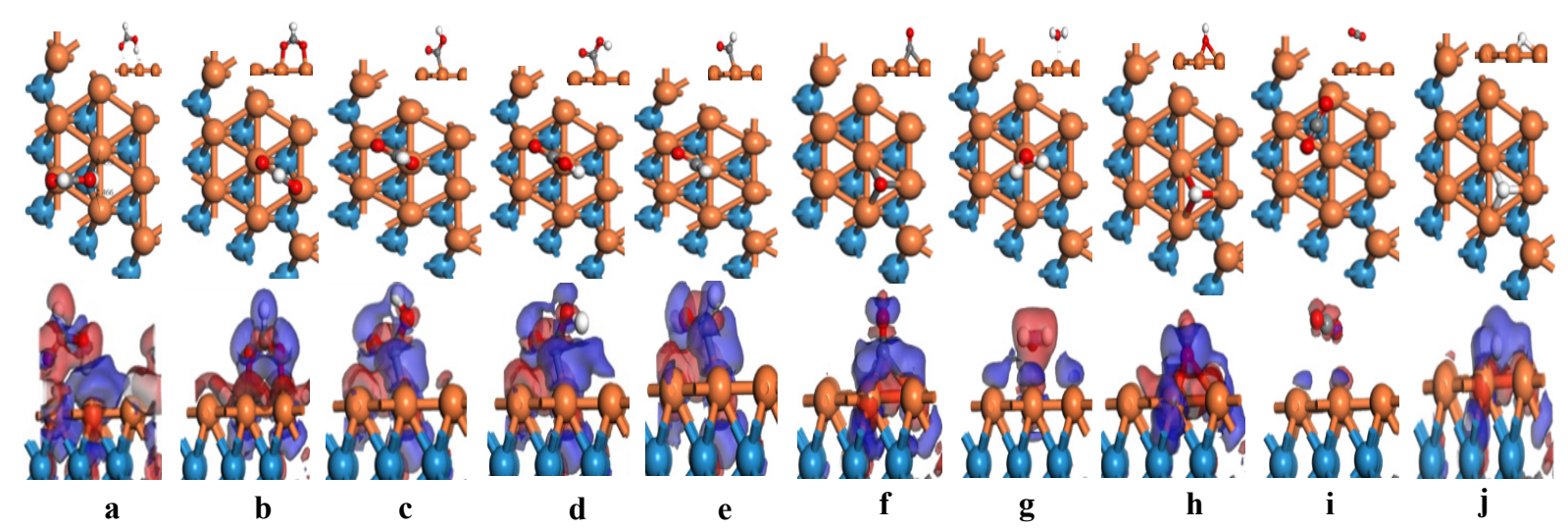

Fig. 1. The upper panels of each represent top-views of the most stable adsorption configurations of different reaction intermediates (built-in side-views in top right upper corner), involved in $\mathrm{HCOOH}$ decomposition, on Pd/WC(0001). The bottom-panels of each represent side-views of electron density difference of corresponding intermediates, respectively. Red, orange, blue, gray and white balls represent $\mathrm{O}$ atoms, $\mathrm{Pd}$ atoms, $\mathrm{W}$ atoms, $\mathrm{C}$ atoms and $\mathrm{H}$ atoms, respectively.

charge region, whereas the red-colored portion indicates the lost charge region.

Among two isomers of formic acid, the trans- $\mathrm{HCOOH}$ configuration is more stable than the cis- $\mathrm{HCOOH}$ configuration in the gaseous phase. Moreover, there are several adsorption configurations of formic acid on Pd/WC(0001) surface. For instance, the formic acid molecular plane can be parallel or perpendicular to the catalyst surface. In addition, there are different adsorption sites in the vertical configuration. Fig. 1(a) presents the most stable adsorption configuration for $\mathrm{HCOOH}$, where carbonyl oxygen is combined with the top site of the Pd atom and the O-Pd distance is $2.30 \AA$ A. Moreover, the $\mathrm{OH}$ group points asymmetrically to two the adjacent Pd atoms and the distance between adjacent $\mathrm{H}$ and Pd atoms is 2.46 and $2.47 \AA$, respectively. Also, the 0 - $\mathrm{H}$ bond lengthened from 0.98 to $1.11 \AA$ with increasing $0.13 \AA$. The calculated adsorption energy of $\mathrm{HCOOH}$ is $-0.87 \mathrm{eV}$, which indicates that the process is energetically favorable.

HCOO also exhibited two different adsorption configura- tions: bidentate (Fig. 1(b)) and monodentate (Fig. 2(i)), where bidentate configuration is more stable than monodentate configuration due to total energy. In monodentate adsorption, only one $\mathrm{O}$ atom is bound to the $\mathrm{Pd}$ atom on the surface and the $\mathrm{C}-\mathrm{H}$ bond obliquely points to the adjacent Pd atom with the adsorption energy of $-2.56 \mathrm{eV}$. In the bidentate model, there is only one type of bidentate adsorption configuration, where two 0 atoms are combined with two adjacent $\mathrm{Pd}$ atoms, respectively, and the $\mathrm{C}-\mathrm{H}$ bond is vertically upward. Herein, the whole $\mathrm{HCOO}$ molecule is located on the bridge site of two $\mathrm{Pd}$ atoms. The two oxygen atoms of HCOO strongly interact with Pd/WC(0001) surface and form two O-Pd bonds with a bond length of $2.18 \AA$. Moreover, the $\mathrm{C}=0$ bond is elongated from 1.268 to $1.273 \AA$ in the gaseous phase. In general, the adsorption process is exothermic $(3.51 \mathrm{eV})$, which indicates strong chemical adsorption. It can be seen from the electron density difference of HCOO (Fig. 1(b)) that more charge transferred between the surface Pd atoms and HCOO, resulting in a stronger O-Pd bond.

In the case of $\mathrm{COOH}$, four adsorption sites and two isomers

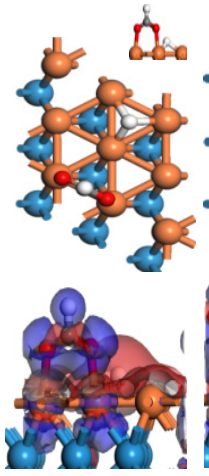

a
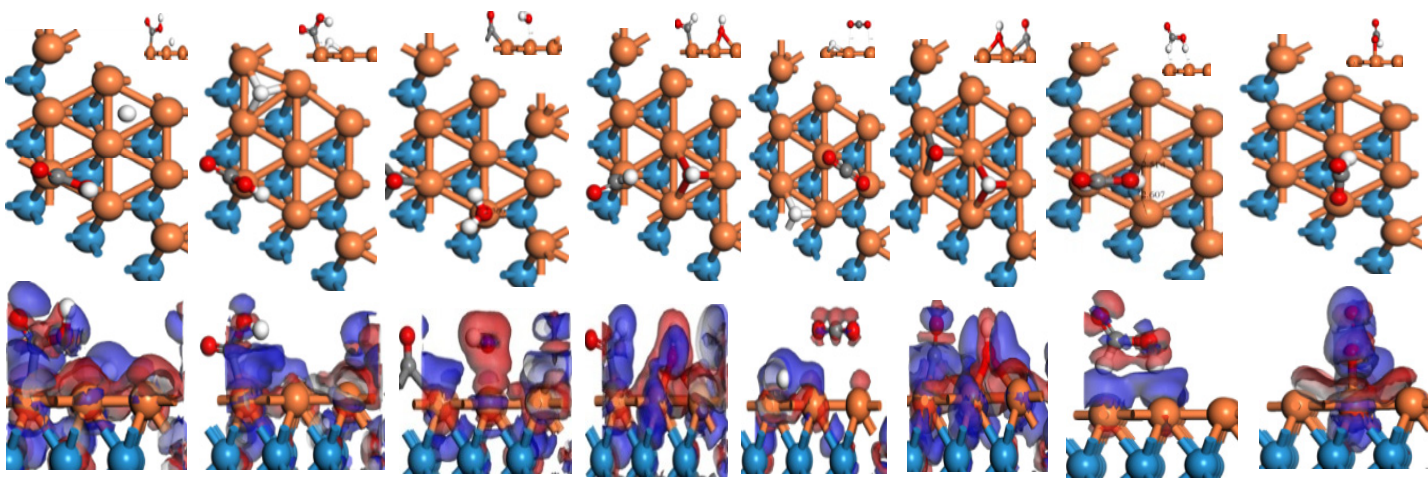

b

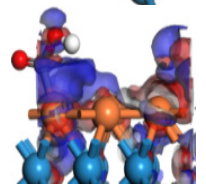

c

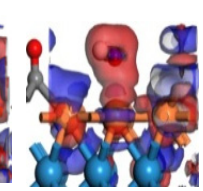

d

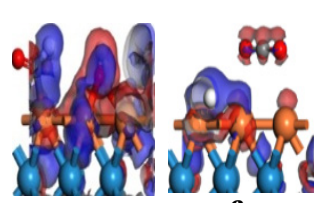

e

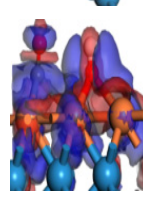

g

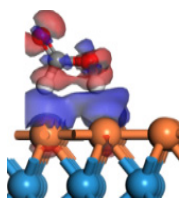

h

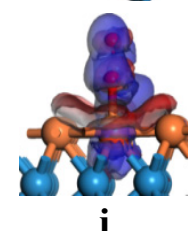

Fig. 2. The upper panels of each represent top-views of the optimized co-adsorption structures of different products (built-in side-views in top right upper corner), involved in $\mathrm{HCOOH}$ decomposition, on Pd/WC(0001). The bottom-panels of each represent side-views of electron density difference of corresponding co-adsorption products, respectively. 
(cis- $\mathrm{COOH}$ and trans-COOH) are considered. Cis- $\mathrm{COOH}$ configuration is less stable than the trans- $\mathrm{COOH}$ configuration in the gaseous phase due to total energy. It has been observed that cis- $\mathrm{COOH}$ and trans- $\mathrm{COOH}$ configurations, adsorbed on the top site of $\mathrm{Pd} / \mathrm{WC}(0001)$ surface, are the most stable structures (Fig. 1(c) and 1(d)) with the adsorption energies of -2.68 and $-2.57 \mathrm{eV}$, respectively. Both $\mathrm{C}$ atoms are bonded to $\mathrm{Pd}$ atom with the C-Pd bond length of 2.05 and $2.09 \AA$, respectively. Moreover, the $\mathrm{C}=0$ bond is almost parallel to the $\mathrm{Pd} / \mathrm{WC}(0001)$ surface.

In the case of free $\mathrm{HCO}$ in the gaseous phase, the $\mathrm{C}=\mathrm{O}$ bond length is $1.19 \AA$ and $\mathrm{H}-\mathrm{C}=0$ bond angle is $123.1^{\circ}$, which are consistent with the experimental values of $1.17 \AA$ and $127^{\circ}$ [56]. On the Pd/WC(0001) surface, HCO tends to adsorb at the bridge site of Pd/WC(0001) surface (Fig. 1(e)), where the C atom is bonded to the $\mathrm{Pd}$ atom on the top site, $\mathrm{C}=\mathrm{O}$ bond occupies the bridge site and becomes parallel to the surface. The $\mathrm{H}-\mathrm{C}=\mathrm{O}$ bond angle was found to be $115.7^{\circ}$. The bond length of C-Pd, O-Pd and C=O bonds is 2.04, 2.31 and $1.25 \AA$, respectively. Moreover, the exothermic energy of $2.26 \mathrm{eV}$ indicates a strong chemical adsorption.

Furthermore, CO stably adsorbed on four high symmetry sites of Pd/WC(0001). The preferential adsorption of CO occurred at the FCC site of Pd/WC(0001) surface with an adsorption energy of $-1.51 \mathrm{eV}$ (Fig. 1(f)). In addition, the $\mathrm{C}-\mathrm{O}$ bond axis is perpendicular to the $\mathrm{Pd} / \mathrm{WC}(0001)$ surface with a C-O bond length of $1.18 \AA$. The distance between $\mathrm{C}$ atom and the nearest Pd atom is $2.21 \AA$. The previous studies reported that CO preferentially adsorbs on the hollow sites of $\mathrm{Pt}(111)$ [56] and Pd(111) [17] surfaces.

Moreover, we have investigated all adsorption sites for $\mathrm{H}_{2} \mathrm{O}$. The results reveal that $\mathrm{H}_{2} \mathrm{O}$ is only adsorbed on the top site of Pd/WC (0001) surface (Fig. 1(g)), where the oxygen atom is directly above the bound $\mathrm{Pd}$ atom with the O-Pd distance of $2.36 \AA$ and $\mathrm{H}_{2} \mathrm{O}$ molecule is almost parallel to the $\mathrm{Pd} / \mathrm{WC}$ (0001) surface. The $\mathrm{H}-\mathrm{O}$ bond length and $\mathrm{H}-\mathrm{O}-\mathrm{H}$ bond angle are $0.978 \AA$ and $104.3^{\circ}$, respectively, which are close to the values of $\mathrm{H}_{2} \mathrm{O}$ molecules in the gaseous phase $(0.98 \AA$ and $103.68^{\circ}$ ). In addition, the corresponding adsorption energy of $-0.60 \mathrm{eV}$ indicates weak adsorption of water molecules on $\mathrm{Pd} / \mathrm{WC}$ (0001) surface.

In the case of $\mathrm{OH}$, it has been observed that $\mathrm{OH}$ cannot be stably adsorbed on the top site, whereas it can be stably adsorbed at the FCC site. $\mathrm{OH}$ is connected to the surrounding three Pd atoms through the oxygen atom (Fig. 1(h)), where $\mathrm{O}-\mathrm{H}$ bond is perpendicular to the surface. At the FCC site, the adsorption energy of $-3.51 \mathrm{eV}$ is slightly higher than the HCP site, which exhibits the strong chemical adsorption. The closest distance between the oxygen atom and three Pd atoms is $2.29 \AA$, whereas the length of $\mathrm{O}-\mathrm{H}$ bond is slightly reduced from 0.99 to $0.973 \AA$ A in vacuum.

In the case of $\mathrm{CO}_{2}$, it has been reported that $\mathrm{CO}_{2}$ prefers to remain as a free specie rather than adsorbed on the metal surfaces [58]. $\mathrm{CO}_{2}$ is far from the $\mathrm{Pd} / \mathrm{WC}(0001)$ surface, where $\mathrm{O}=\mathrm{C}=\mathrm{O}$ bond angle and $\mathrm{C}=\mathrm{O}$ bond length are close to the $\mathrm{CO}_{2}$ molecule in the gas phase (Fig. 1(i)). It is found that the interaction between $\mathrm{CO}_{2}$ and $\mathrm{Pd} / \mathrm{WC}(0001)$ surface is weak and the adsorption energy is $-0.29 \mathrm{eV}$, which is consistent with the experimental results. This can be seen from the top- and side-views of electron density difference of $\mathrm{CO}_{2}$ with little charge transfer between the $\mathrm{CO}_{2}$ and the surface (Fig. 1(i)).

Four stable adsorption sites have been observed for $\mathrm{H}$, which preferentially adsorbs on the FCC site on the Pd/WC (0001) surface with an adsorption energy of $-2.67 \mathrm{eV}$ (Fig. 1(j)). The $\mathrm{H}$ atom is closer to the surface and the minimum distance between $\mathrm{H}$ and three nearby Pd atoms is $1.92 \AA$.

In summary, the adsorption of $\mathrm{HCOOH}, \mathrm{HCOO}$, trans- $\mathrm{COOH}$, cis- $\mathrm{COOH}, \mathrm{HCO}, \mathrm{CO}, \mathrm{H}_{2} \mathrm{O}, \mathrm{OH}$ and $\mathrm{H}$ on $\mathrm{Pd} / \mathrm{WC}(0001)$ surface followed the chemisorption process. However, cis-HCOOH and $\mathrm{CO}_{2}$ can be considered as physisorption due to their weak interaction with Pd/WC(0001) surface.

It has been observed that $\mathrm{HCOOH}$, trans- $\mathrm{COOH}$, cis- $\mathrm{COOH}$ and $\mathrm{H}_{2} \mathrm{O}$ preferentially adsorb on the top sites; $\mathrm{HCOO}$, mHCOO and $\mathrm{HCO}$ occupy the bridge sites; and $\mathrm{CO}, \mathrm{H}$ and $\mathrm{OH}$ adsorb on FCC sites. There is charge transfer from Pd to the carrier, with an average of 0.13 electron per Pd atom. Compared with $\operatorname{Pd}(111)$ surface [17], the corresponding adsorption energies of all species are distinctly different in the case of Pd/WC(0001) surface, which can be ascribed to the different arrangement of Pd atoms and synergy between WC carrier and monolayer Pd.

\subsection{Co-adsorption on $P d / W C(0001)$ surface}

In order to investigate the decomposition mechanism of $\mathrm{HCOOH}$ on Pd/WC(0001) surface, the most stable co-adsorption configurations of (a) $\mathrm{HCOO}+\mathrm{H}$, (b) cis- $\mathrm{COOH}+$ $\mathrm{H},\left(\right.$ c) trans- $\mathrm{COOH}+\mathrm{H}$, (d) $\mathrm{CO}+\mathrm{H}_{2} \mathrm{O}$, (e) $\mathrm{HCO}+\mathrm{OH}$, (f) $\mathrm{CO}_{2}+\mathrm{H}$ and $(\mathrm{g}) \mathrm{CO}+\mathrm{OH}$ have been studied. The combined configurations are selected based on the final product of $\mathrm{HCOOH}$ decomposition. The optimized co-adsorption configurations are shown in Fig. 2, whereas the corresponding adsorption sites and co-adsorption energies are summarized in Table 2.

In all calculations, for the initial co-adsorption configuration on the Pd/WC(0001) surface, the corresponding intermediates are located at the adjacent and the most stable adsorption sites. For example, for the co-adsorption of $\mathrm{HCOO}+\mathrm{H}$ on $\mathrm{Pd} / \mathrm{WC}(0001)$ surface, the initial structure is that $\mathrm{H}$ atom is located on fcc sites and HCOO is on the adjacent bridge sites. After geometric optimization, it is found that most of the optimized co-adsorption configurations maintain their initial state. The co-adsorption energies of $\mathrm{HCOO}+\mathrm{H}$, cis- $\mathrm{COOH}+\mathrm{H}$, trans- $\mathrm{COOH}+\mathrm{H}, \mathrm{CO}+\mathrm{H}_{2} \mathrm{O}, \mathrm{HCO}+\mathrm{OH}, \mathrm{CO}_{2}+\mathrm{H}$ and $\mathrm{CO}+\mathrm{OH}$ are

Table 2

The most stable co-adsorption structures on Pd/WC(0001) surface and corresponding co-adsorption energies.

\begin{tabular}{lcc}
\hline Species & Corresponding adsorption sites & $E_{\text {coads }} / \mathrm{eV}$ \\
\hline $\mathrm{HCOO}+\mathrm{H}$ & bridge + fcc & -6.17 \\
cis- $\mathrm{COOH}+\mathrm{H}$ & top $+\mathrm{fcc}$ & -5.14 \\
trans- $\mathrm{COOH}+\mathrm{H}$ & top + fcc & -5.21 \\
$\mathrm{CO}+\mathrm{H}_{2} \mathrm{O}$ & fcc + top & -2.19 \\
$\mathrm{HCO}+\mathrm{OH}$ & bridge + fcc & -5.34 \\
$\mathrm{CO}_{2}+\mathrm{H}$ & $---\quad+$ fcc & -2.98 \\
$\mathrm{CO}+\mathrm{OH}$ & fcc + fcc & -4.54 \\
\hline
\end{tabular}


Table 3

Energy barrier $\left(E_{\mathrm{b}}\right)$ and reaction energy $(\Delta H)$ of the $\mathrm{HCOOH}$ decomposition reactions on $\mathrm{Pd} / \mathrm{WC}(0001)$ surface.

\begin{tabular}{|c|c|c|c|c|}
\hline Reaction & TS & Reaction & $E_{\mathrm{b}} / \mathrm{eV}$ & $\Delta H / \mathrm{eV}$ \\
\hline $\mathrm{HCOOH} \rightarrow \mathrm{HCOO}+\mathrm{H}$ & TS1 & $\mathrm{R} 1$ & 0.61 & -0.60 \\
\hline $\mathrm{HCOOH} \rightarrow$ cis- $\mathrm{COOH}+\mathrm{H}$ & TS2 & $\mathrm{R} 2$ & 0.77 & 0.19 \\
\hline $\mathrm{HCOOH} \rightarrow \mathrm{CO}+\mathrm{H}_{2} \mathrm{O}$ & TS3 & R3 & 0.93 & -0.37 \\
\hline $\mathrm{HCOOH} \rightarrow \mathrm{HCO}+\mathrm{OH}$ & TS4 & $\mathrm{R} 4$ & 1.05 & 0.67 \\
\hline $\mathrm{HCOOH} \rightarrow$ cis- $\mathrm{HCOOH}$ & TS5 & R5 & 0.62 & 0.58 \\
\hline cis- $\mathrm{HCOOH} \rightarrow \mathrm{HCO}+\mathrm{OH}$ & TS6 & R6 & 0.46 & 0.09 \\
\hline cis- $\mathrm{HCOOH} \rightarrow$ trans $-\mathrm{COOH}+\mathrm{H}$ & TS7 & R7 & 0.12 & -0.53 \\
\hline $\mathrm{HCO}+\mathrm{OH} \rightarrow \mathrm{CO}+\mathrm{H}_{2} \mathrm{O}$ & TS8 & R8 & 0.23 & -1.05 \\
\hline $\mathrm{HCOO} \rightarrow \mathrm{CO}_{2}+\mathrm{H}$ & TS9 & R9 & 1.09 & 0.53 \\
\hline $\mathrm{HCOO} \rightarrow \mathrm{mHCOO}$ & TS10 & R10 & 1.05 & 0.95 \\
\hline $\mathrm{HCOO} \rightarrow$ cis-COOH & TS11 & R11 & 2.91 & 0.59 \\
\hline $\mathrm{mHCOO} \rightarrow \mathrm{CO}_{2}+\mathrm{H}$ & TS12 & $\mathrm{R} 12$ & 0.21 & -0.37 \\
\hline trans- $\mathrm{COOH} \rightarrow$ cis- $\mathrm{COOH}$ & TS13 & R13 & 0.52 & -0.03 \\
\hline tans- $\mathrm{COOH} \rightarrow \mathrm{CO}+\mathrm{OH}$ & TS14 & $\mathrm{R} 14$ & 0.16 & -0.05 \\
\hline trans- $\mathrm{COOH} \rightarrow \mathrm{CO}_{2}+\mathrm{H}$ & TS15 & $\mathrm{R} 15$ & 1.37 & -0.09 \\
\hline cis- $\mathrm{COOH} \rightarrow \mathrm{CO}+\mathrm{OH}$ & TS16 & R16 & 0.47 & -0.01 \\
\hline cis- $\mathrm{COOH} \rightarrow \mathrm{CO}_{2}+\mathrm{H}$ & TS17 & $\mathrm{R} 17$ & 1.27 & 0.28 \\
\hline
\end{tabular}

$-6.17,-5.14,-5.21,-2.19,-5.34,-2.98$ and $-4.54 \mathrm{eV}$, respectively.

\subsection{Decomposition of adsorbed intermediates on $\mathrm{Pd} / \mathrm{WC}(0001)$ surface}

Furthermore, the possible reaction pathways of $\mathrm{HCOOH}$ decomposition on Pd/WC(0001) surface are systematically studied. Initially, the trans- $\mathrm{HCOOH}$ configuration is used based on the $\mathrm{HCOOH}$ bond cleavage and configuration flipping pathway (Fig. 1(a)). In the bond cleavage, the decomposition starts from the formation of (I) HCOO by O-H bond cleavage, (II) cis- $\mathrm{COOH}$ by $\mathrm{C}-\mathrm{H}$ bond cleavage, (III) $\mathrm{CO}$ and $\mathrm{H}_{2} \mathrm{O}$ by simultaneous bond

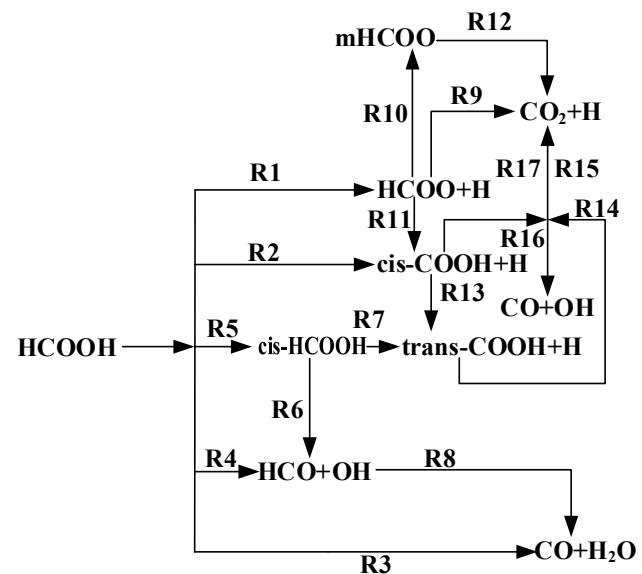

Fig. 4. The network of reaction steps for $\mathrm{HCOOH}$ decomposition on Pd/WC(0001) surface.

cleavage of $\mathrm{C}-\mathrm{H}$ and $\mathrm{O}-\mathrm{H}$ bond and (IV) $\mathrm{HCO}$ and $\mathrm{OH}$ by $\mathrm{C}-\mathrm{O}$ bond cleavage. In the configuration flipping, $\mathrm{C}=\mathrm{O}$ and $\mathrm{C}-\mathrm{H}$ bonds in trans-HCOOH configuration (Fig. 1(a)) are rotated at $180^{\circ}$ along the $\mathrm{C}-\mathrm{O}$ bond, resulting in cis- $\mathrm{HCOOH}$ configuration (Fig. 2(h)). Moreover, the configurational transitions and dissociation pathways between $\mathrm{HCOO}$, mHCOO, cis- $\mathrm{COOH}$ and trans-COOH have been investigated by using DFT. The reaction energy barriers $\left(E_{\mathrm{b}}\right)$ and reaction energies $(\Delta H)$ of each reaction are calculated and results are summarized in Table 3.

The relevant transition states (TS) of the elementary reactions are shown in Fig. 3 and the reaction network of $\mathrm{HCOOH}$ decomposition is presented in Fig. 4. Among all the possible routes, the most stable adsorption structure of the intermediates on $\mathrm{Pd} / \mathrm{WC}(0001)$ surface is selected as the initial reactant. Moreover, the final reaction products are considered as the

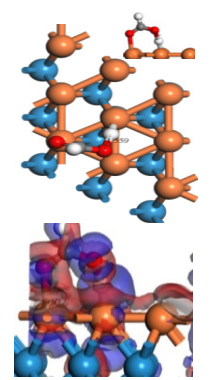

TS1

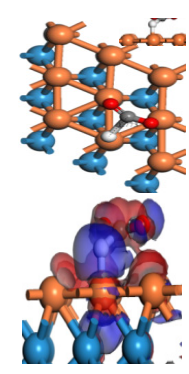

TS9

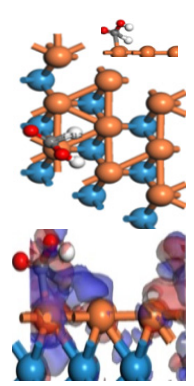

TS2



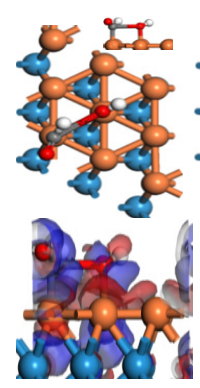

TS3

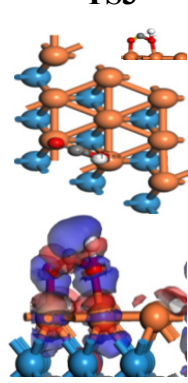

TS11

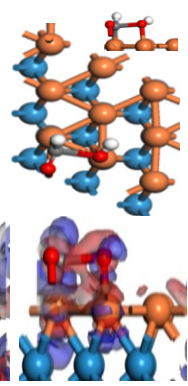

TS4

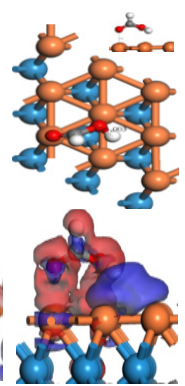

TS5
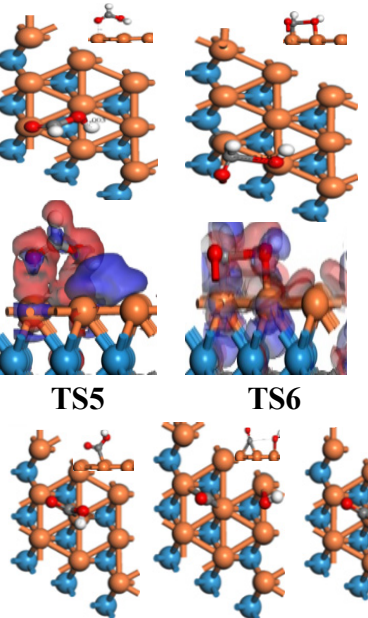

TS6

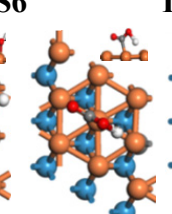

TS7
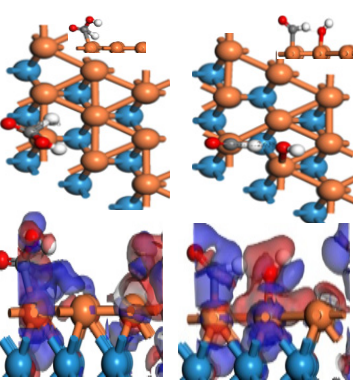

TS8
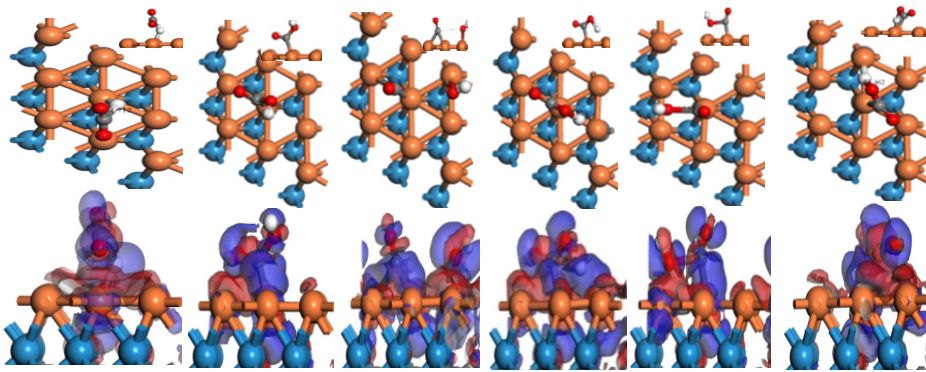

TS13

TS14
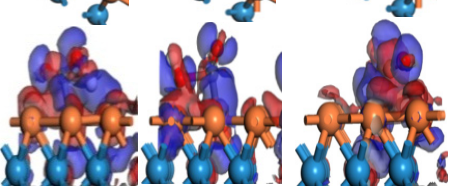

TS12

TS15

TS16

TS17

Fig. 3. The upper panels of each represent top-views of the TS (built-in side-views in top right upper corner) on Pd/WC(0001). The bottom-panels of each represent side-views of electron density difference of corresponding TS, respectively. 
corresponding co-adsorption configurations of the most stable monomer adsorption sites.

\subsubsection{The scission of $\mathrm{O}-\mathrm{H}, \mathrm{C}-\mathrm{H}$ and $\mathrm{C}-\mathrm{O}$ bonds of $\mathrm{HCOOH}$ on $\mathrm{Pd} / \mathrm{WC}(0001)$ surface}

Four bond cleavage pathways are considered to investigate the decomposition of $\mathrm{HCOOH}$ on Pd/WC (0001) surface.

(I) $\mathrm{HCOOH} \rightarrow \mathrm{HCOO}+\mathrm{H}$ : Once the $\mathrm{O}-\mathrm{H}$ bond is broken, the adsorbed $\mathrm{HCOOH}$ (Fig. 1(a)) is decomposed into $\mathrm{HCOO}$ and $\mathrm{H}$ in TS1 (Fig. 3). The dissociated $\mathrm{H}$ atom migrates to the vicinity of FCC site and the $\mathrm{O}$ atom of $\mathrm{C}-\mathrm{O}$ bond moves to the top site of the adjacent $\mathrm{Pd}$ atom. The distance between the dissociated $\mathrm{H}$ and 0 atoms increases to $1.56 \AA$, which is an increase of $0.54 \AA$ from the initial bond length of $1.02 \AA$. After TS1, the dissociated $\mathrm{H}$ atom is located at the FCC site and the bidentate HCOO is adsorbed on two adjacent Pd atoms by forming 0-Pd bonds. The activation and exothermic energies of the elementary reaction are 0.61 and $0.60 \mathrm{eV}$, respectively. In terms of adsorption energy, $\mathrm{HCOOH}$ is more prone to dissociation on $\mathrm{Pd} / \mathrm{WC}(0001)$ surface than desorption.

(II) $\mathrm{HCOOH} \rightarrow$ cis- $\mathrm{COOH}+\mathrm{H}$ : With the cleavage of $\mathrm{C}-\mathrm{H}$ bond, $\mathrm{HCOOH}$ (Fig. 1(a)) is decomposed into cis- $\mathrm{COOH}$ and $\mathrm{H}$ in the vicinity of top and FCC sites in TS2, respectively (Fig. 3). The $\mathrm{C}-\mathrm{H}$ bond length is extended to $1.51 \AA$ and the reaction overcomes the energy barrier of $0.77 \mathrm{eV}$, whereas the endothermic energy is $0.19 \mathrm{eV}$. In terms of adsorption energy, $\mathrm{HCOOH}$ is more prone to dissociation on $\mathrm{Pd} / \mathrm{WC}(0001)$ surface than desorption.

(III) $\mathrm{HCOOH} \rightarrow \mathrm{CO}+\mathrm{H}_{2} \mathrm{O}$ : With the simultaneous cleavage of $\mathrm{C}-\mathrm{H}$ and $\mathrm{C}-\mathrm{O}$ bonds, HCOOH (Fig. 1(a)) is decomposed into $\mathrm{H}$, $\mathrm{CO}$ and $\mathrm{OH}$ on top sites in TS3 (Fig. 3). After TS3, CO moves to the nearby FCC site and the dissociated $\mathrm{H}$ atom combines with $\mathrm{OH}$ and forms $\mathrm{H}_{2} \mathrm{O}$ to remain on the top site. The reaction overcomes an energy barrier of $0.93 \mathrm{eV}$ and exhibits exothermic energy of $0.37 \mathrm{eV}$.

(IV) $\mathrm{HCOOH} \rightarrow \mathrm{HCO}+\mathrm{OH}$ : With the cleavage of $\mathrm{C}-\mathrm{O}$ bond, $\mathrm{HCOOH}$ is decomposed into co-adsorbed $\mathrm{HCO}$ and $\mathrm{OH}$, occupying the vicinity of two adjacent top sites. In TS4, the distance between the oxygen atom of $\mathrm{OH}$ and $\mathrm{C}$ atom is $2.15 \AA$ (Fig. 3). After TS4, HCO remains on the top site and $\mathrm{OH}$ moves to the nearby FCC site. The activation energy and endothermic energy of the elementary reaction are 1.05 and $0.67 \mathrm{eV}$, respectively.

(V) $\mathrm{HCOOH} \rightarrow$ cis- $\mathrm{HCOOH}$ : cis-HCOOH (Fig. 2(h)) is the adsorption configuration after $\mathrm{HCOOH}$ conversion. Even though it is not as stable as the initial reaction of $\mathrm{HCOOH}$ (Fig. 1(a)), it is beneficial to subsequent decomposition. Two $\mathrm{H}$ atoms of cis- $\mathrm{HCOOH}$ configuration lie on the same side and point towards $\mathrm{Pd} / \mathrm{WC}(0001)$ surface. $\mathrm{HCOOH}$ to cis- $\mathrm{HCOOH}$ transformation occurs by simultaneous reorientation of $\mathrm{C}-\mathrm{H}$ and $\mathrm{C}=\mathrm{O}$ bonds around $180^{\circ}$ along the $\mathrm{C}-\mathrm{O}$ bond. One should note that $\mathrm{C}=\mathrm{O}$ and $\mathrm{C}-\mathrm{H}$ bond lengths in TS5 are still 1.22 and $1.10 \AA$ A, respectively. However, the position of $\mathrm{C}=\mathrm{O}$ and $\mathrm{C}-\mathrm{H}$ bonds deviated from the original vertical position. This process overcomes an energy barrier of $0.62 \mathrm{eV}$ and exhibits an endothermic energy of $0.58 \mathrm{eV}$.

(VI) cis- $\mathrm{HCOOH} \rightarrow \mathrm{HCO}+\mathrm{OH}$ : Once $\mathrm{C}-\mathrm{O}$ bond is broken,
cis-HCOOH configuration decomposes into co-adsorbed HCO and $\mathrm{OH}$, occupying the vicinity of two adjacent top sites on Pd/WC(0001) surface, respectively. In TS6 (Fig. 3), the distance between the oxygen atom of $\mathrm{OH}$ and $\mathrm{C}$ atom is $2.15 \AA$ After TS6, the $\mathrm{HCO}$ remains on the top site and $\mathrm{OH}$ moves to the nearby FCC site. The activation energy and endothermic energy of the elementary reaction are 0.46 and $0.09 \mathrm{eV}$, respectively. It is worth mentioning that this reaction is more favorable than $\mathrm{R} 4$ due to its lower activation energy.

(VII) cis- $\mathrm{HCOOH} \rightarrow$ trans- $\mathrm{COOH}+\mathrm{H}$ : In TS7 (Fig. 3), $\mathrm{C}-\mathrm{H}$ bond is elongated to $1.49 \AA$, trans- $\mathrm{COOH}$ configuration occupies the top site and $\mathrm{H}$ moves to the vicinity of FCC site, which later occupies the FCC site. The reaction overcomes an energy barrier of $0.12 \mathrm{eV}$ and exhibits exothermic energy of $0.53 \mathrm{eV}$.

(VIII) $\mathrm{HCO}+\mathrm{OH} \rightarrow \mathrm{CO}+\mathrm{H}_{2} \mathrm{O}$ : The $\mathrm{HCO}$ and $\mathrm{OH}$, obtained from R4 and R6, further changed to $\mathrm{CO}$ and $\mathrm{H}_{2} \mathrm{O}$ through TS8 (Fig. 3). The lengths of $\mathrm{C}-\mathrm{H}$ and $\mathrm{O}-\mathrm{H}$ bonds are 1.21 and $1.48 \AA$, respectively. After the transition state, the $\mathrm{CO}$ moves to the nearby FCC site and $\mathrm{H}_{2} \mathrm{O}$ occupies the top site. The activation energy and exothermic energy of the reaction are 0.23 and 1.05 $\mathrm{eV}$, respectively.

\subsubsection{The Decomposition of HCOO on Pd/WC(0001) surface}

(I) $\mathrm{HCOO} \rightarrow \mathrm{CO}_{2}+\mathrm{H}$ : The fracture of $\mathrm{C}-\mathrm{H}$ bond in bidentate HCOO is selected (Fig. 1(b)) as an initial state, which is directly dissociated into $\mathrm{CO}_{2}$ and $\mathrm{H}$ by TS9. In TS9, the distance between the dissociated $\mathrm{H}$ and $\mathrm{C}$ atoms extends from 1.11 to $1.52 \AA$ and $\mathrm{H}$ atom occupies the top site. In the co-adsorbed state, $\mathrm{CO}_{2}$ molecule is far from the surface and $\mathrm{H}$ atom is on the FCC site. The activation energy and endothermic energy of the elemental reaction are 1.09 and $0.53 \mathrm{eV}$, respectively.

(II) HCOO $\rightarrow$ mHCOO: Herein, the reaction occurs by the inversion of adsorption configuration. The bidentate HCOO, adsorbed on the Pd/WC(0001) surface, becomes monodentate HCOO (Fig. 2(i)), where an O-Pd bond breaks and only one 0 atom combines with adjacent Pd atom to form an 0-Pd bond. As a result, $\mathrm{C}-\mathrm{H}$ bond is obliquely directed to adjacent $\mathrm{Pd}$ atom. As shown in Fig. 3 (TS10), the bond length C-H (1.13 ̊̊) did not exhibit any significant change. The reaction energy barrier and endothermic energy are 1.05 and $0.95 \mathrm{eV}$, respectively.

(III) $\mathrm{HCOO} \rightarrow$ cis- $\mathrm{COOH}$ : The $\mathrm{C}-\mathrm{H}$ bond in $\mathrm{HCOO}$ breaks and $\mathrm{H}$ atom moves to the adjacent $\mathrm{O}$ atom to form cis-COOH. In TS11 (Fig. 3), the bond lengths of $\mathrm{C}-\mathrm{H}$ and $\mathrm{O}-\mathrm{H}$ bonds become 1.35 and $1.19 \AA$ A respectively. The activation energy and endothermic energy of the elementary reaction are 2.91 and $0.59 \mathrm{eV}$, respectively.

(IV) $\mathrm{mHCOO} \rightarrow \mathrm{CO}_{2}+\mathrm{H}$ : The $\mathrm{C}-\mathrm{H}$ bond of the monodentate $\mathrm{HCOO}$ breaks to form $\mathrm{CO}_{2}$ and $\mathrm{H}$. In TS12 (Fig. 3), the $\mathrm{C}-\mathrm{H}$ bond is elongated to $1.71 \AA$. The activation energy and exothermic energy of the reaction are 0.21 and $0.37 \mathrm{eV}$, respectively.

\subsubsection{Decomposition of $\mathrm{COOH}$ on $\mathrm{Pd} / \mathrm{WC}(0001)$ surface}

In the case of $\mathrm{COOH}$, the total energy of trans- $\mathrm{COOH}$ and cis- $\mathrm{COOH}$ configurations on $\mathrm{Pd} / \mathrm{WC}(0001)$ surface is not much different. Hence, the configuration conversion and decomposi- 
tion between the two are studied, which resulted in five different reaction pathways.

(I) Trans-COOH $\rightarrow$ cis-COOH: During cis-COOH to trans- $\mathrm{COOH}$ transition (TS13), $\mathrm{C}$ atom exists in the vicinity of the original top site, where $\mathrm{O}-\mathrm{H}$ bond is reversed and changes from original oblique downward to the oblique side and attains a final oblique upward position (Fig. 3). However, the bond length of $\mathrm{O}-\mathrm{H}$ bond is still $0.98 \AA$ A. This energy barrier and exothermic energy of the given reaction are 0.52 and $0.03 \mathrm{eV}$, respectively.

(II) Tans- $\mathrm{COOH} \rightarrow \mathrm{CO}+\mathrm{OH}$ : During the cleavage of $\mathrm{C}-\mathrm{O}$ bond of trans-COOH configuration on Pd/WC (0001) surface, the initial state is trans-COOH adsorbed on the top site (Fig. 1(d)). In TS14 (Fig. 3), the $\mathrm{C}$ atom is located near the original Pd atom and $\mathrm{O}-\mathrm{H}$ bond is flipped and moved to the adjacent bridge site. After TS14, $\mathrm{CO}$ and $\mathrm{OH}$ are located on the FCC sites. The reaction exhibits an energy barrier and exothermic energy of 0.16 and $0.05 \mathrm{eV}$, respectively.

(III) Trans- $\mathrm{COOH} \rightarrow \mathrm{CO}_{2}+\mathrm{H}$ : Trans- $\mathrm{COOH}$ configuration results in $\mathrm{CO}_{2}$ and $\mathrm{H}$ via TS15, as shown in Fig. 3. The distance between dissociated $\mathrm{H}$ and $\mathrm{O}$ atom increased from 0.98 to 1.53 $\AA$ A. After TS15, the dissociated $\mathrm{H}$ atom moves to the adjacent FCC site and the $\mathrm{CO}_{2}$ molecule moves away from the surface. The reaction needs to overcome the energy barrier of $1.37 \mathrm{eV}$ and exhibits exothermic energy of $0.09 \mathrm{eV}$.

(IV) Cis- $\mathrm{COOH} \rightarrow \mathrm{CO}+\mathrm{OH}$ : During the cleavage of $\mathrm{C}-\mathrm{O}$ bond of cis- $\mathrm{COOH}$ configuration on $\mathrm{Pd} / \mathrm{WC}$ (0001) surface, the initial state is the cis- $\mathrm{COOH}$ configuration, as shown in Fig. 1(c). Herein, $\mathrm{OH}$ dissociates from the adsorbed cis- $\mathrm{COOH}$ configuration and co-adsorbs with remaining CO. In TS16 (Fig. 3), the distance between the oxygen atom, dissociated from $\mathrm{OH}$, and $\mathrm{C}$ atom increased to $1.88 \AA$ A. After TS16, both $\mathrm{CO}$ and $\mathrm{OH}$ occupied the adjacent FCC sites. The reaction exhibited an energy barrier of $0.47 \mathrm{eV}$ and exothermic energy of $0.01 \mathrm{eV}$.

(V) Cis- $\mathrm{COOH} \rightarrow \mathrm{CO}_{2}+\mathrm{H}$ : During the cleavage of $\mathrm{O}-\mathrm{H}$ bond of cis- $\mathrm{COOH}$ configuration, $\mathrm{CO}_{2}$ and $\mathrm{H}$ are generated according to TS17, as shown in Fig. 3. In TS17, the distance between dissociated $\mathrm{H}$ and $\mathrm{O}$ atoms increased from 0.99 to $1.42 \AA$ and $\mathrm{O}-\mathrm{H}$ bond points towards $\mathrm{Pd} / \mathrm{WC}(0001)$ surface. After TS17, $\mathrm{CO}_{2}$ molecule moves away from the surface and dissociated $\mathrm{H}$ atom moves to the adjacent FCC site. The reaction needs to overcome an energy barrier of $1.27 \mathrm{eV}$ and exhibits endothermic energy of $0.28 \mathrm{eV}$.

\subsubsection{The brief summary}

The potential energy surface for $\mathrm{HCOOH}$ decomposition through $\mathrm{HCOO}$, mHCOO, cis- $\mathrm{HCOOH}$, cis- $\mathrm{COOH}$, trans- $\mathrm{COOH}$ and HCO intermediates on Pd/WC(0001) surface is shown in Figs. 5 and 6, which includes the following pathways (Fig. 4):

(1) $\mathrm{HCOOH} \rightarrow \mathrm{HCOO} \rightarrow \mathrm{CO}_{2}$;

(2) $\mathrm{HCOOH} \rightarrow \mathrm{HCOO} \rightarrow \mathrm{mHCOO} \rightarrow \mathrm{CO}_{2}$;

(3) $\mathrm{HCOOH} \rightarrow$ cis- $\mathrm{HCOOH} \rightarrow \mathrm{HCO} \rightarrow \mathrm{CO}$;

(4) $\mathrm{HCOOH} \rightarrow$ cis- $\mathrm{HCOOH} \rightarrow$ trans- $\mathrm{COOH} \rightarrow \mathrm{CO}$;

(5) $\mathrm{HCOOH} \rightarrow$ cis- $\mathrm{HCOOH} \rightarrow$ trans- $\mathrm{COOH} \rightarrow \mathrm{CO}_{2}$;

(6) $\mathrm{HCOOH} \rightarrow$ cis- $\mathrm{HCOOH} \rightarrow$ trans- $\mathrm{COOH} \rightarrow$ cis- $\mathrm{COOH} \rightarrow \mathrm{CO}$;

(7) $\mathrm{HCOOH} \rightarrow$ cis- $\mathrm{HCOOH} \rightarrow$ trans- $\mathrm{COOH} \rightarrow$ cis- $\mathrm{COOH} \rightarrow \mathrm{CO}_{2}$;

(8) $\mathrm{HCOOH} \rightarrow$ cis- $\mathrm{COOH} \rightarrow \mathrm{CO}$;

(9) $\mathrm{HCOOH} \rightarrow$ cis- $\mathrm{COOH} \rightarrow \mathrm{CO}_{2}$;

$(10) \mathrm{HCOOH} \rightarrow \mathrm{HCOO} \rightarrow$ cis- $\mathrm{COOH} \rightarrow \mathrm{CO}$;

(11) $\mathrm{HCOOH} \rightarrow \mathrm{HCOO} \rightarrow$ cis- $\mathrm{COOH} \rightarrow \mathrm{CO}_{2}$;

(12) $\mathrm{HCOOH} \rightarrow \mathrm{HCO} \rightarrow \mathrm{CO}$;

(13) $\mathrm{HCOOH} \rightarrow \mathrm{CO}$.

By comparing the adsorption energy and dissociation energy barrier of the intermediates, it is demonstrated that the dissociation of adsorbed $\mathrm{HCOOH}, \mathrm{HCOO}, \mathrm{mHCOO}$, cis- $\mathrm{COOH}$ and trans- $\mathrm{COOH}$ is more favorable on Pd/WC(0001) surface than desorption. According to the corresponding activation energy, $\mathrm{HCOO}$ is the main dissociation intermediate of $\mathrm{HCOOH}$ on $\mathrm{Pd} / \mathrm{WC}(0001)$ surface. One should note that the generation of $\mathrm{CO}_{2}$ is more difficult from $\mathrm{HCOO}$ than the formation of $\mathrm{CO}$ from trans- $\mathrm{COOH}$ and cis- $\mathrm{COOH}$ configurations, which is similar to the decomposition of $\mathrm{HCOOH}$ on the $\mathrm{Pd}(111)$ surface [57] and indicates that $\mathrm{HCOO}$ may accumulate on Pd/WC(0001) surface. $\mathrm{HCOOH}$ is converted into cis- $\mathrm{HCOOH}$ and, then, the trans- $\mathrm{COOH}$ configuration is generated. Overall, $\mathrm{CO}$ is the main dissociation intermediate of trans- $\mathrm{COOH}$ configuration on $\mathrm{Pd} / \mathrm{WC}(0001)$ surface.

Furthermore, the cleavage of $\mathrm{C}-\mathrm{O}$ bond in both cis- and trans- $\mathrm{COOH}$ configuration is easier than $\mathrm{O}-\mathrm{H}$ bond cleavage, which indicates that $\mathrm{CO}$ is formed before $\mathrm{CO}_{2}$. In addition, $\mathrm{CO}$ is directly produced from decomposition of $\mathrm{HCOOH}$ or $\mathrm{HCO}$,
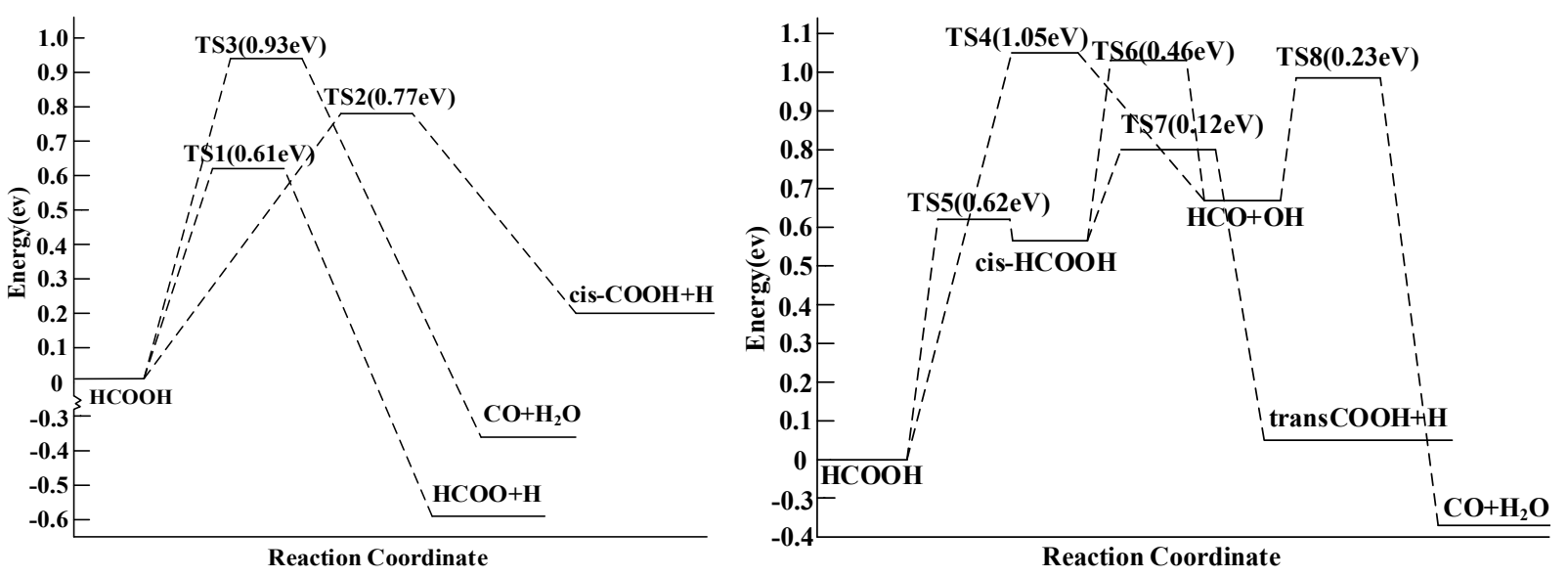

Fig. 5. Potential energy profiles of $\mathrm{HCOOH}$ decomposition on $\mathrm{Pd} / \mathrm{WC}(0001)$ surface. 

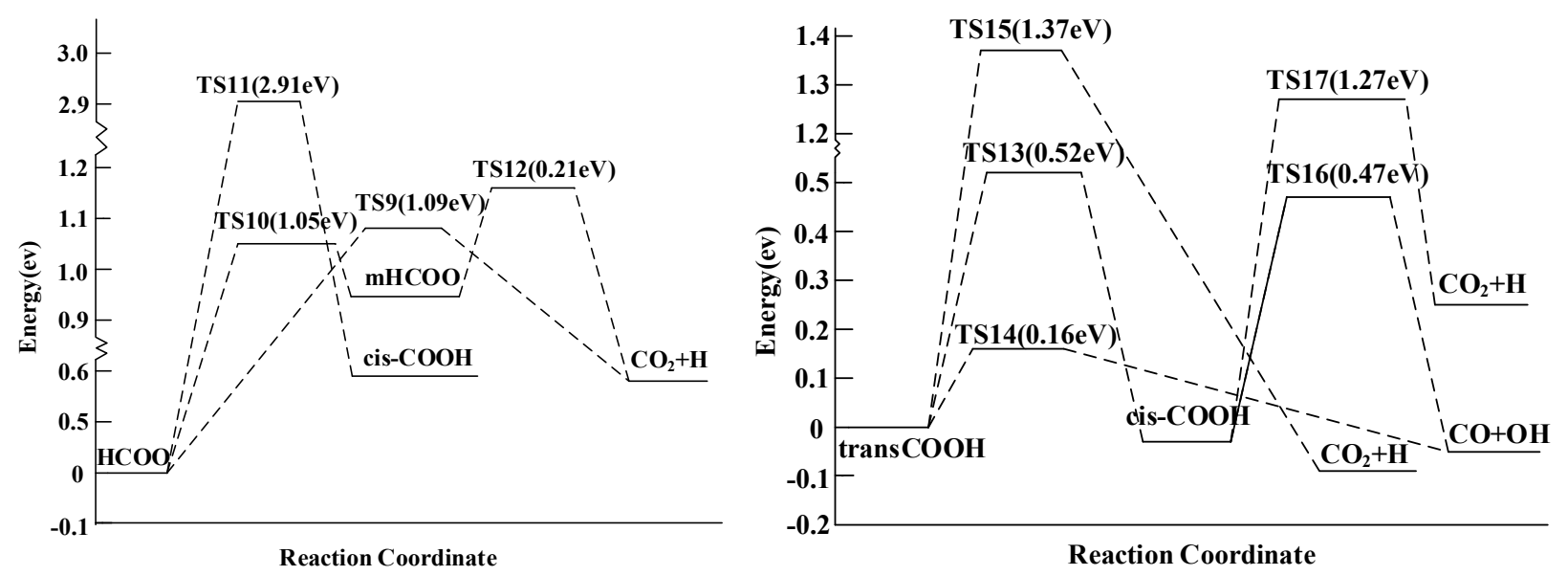

Fig. 6. Potential energy profiles of $\mathrm{HCOO}$, mHCOO, trans-COOH and cis-COOH decomposition on Pd/WC(0001) surface.

however, the probability is extremely low due to the corresponding high energy barrier, as discussed in the case of TS3 and TS4 in Fig. 3. As long as a small part of $\mathrm{HCOOH}$ is converted into cis- $\mathrm{HCOOH}$ through TS5, prior to its decomposition into $\mathrm{HCOO}$, cis- $\mathrm{HCOOH}$ is easily decomposed into $\mathrm{HCO}$ and $\mathrm{OH}$ by TS6, which are rapidly decomposed into CO after TS8. Overall, $\mathrm{HCOOH} \rightarrow \mathrm{HCOO} \rightarrow \mathrm{CO}_{2}$ (Path 1 ) is the most probable pathway of $\mathrm{HCOOH}$ decomposition on $\mathrm{Pd} / \mathrm{WC}(0001)$ surface, where the decomposition of $\mathrm{HCOO}$ into $\mathrm{CO}_{2}$ is the rate-determining step.

\section{Conclusions}

In summary, periodic DFT is utilized to investigate the possible pathways of $\mathrm{HCOOH}$ decomposition on Pd/WC(0001) surface, where the decomposition of $\mathrm{HCOOH}$ is initiated by the activation of $\mathrm{C}-\mathrm{H}, \mathrm{O}-\mathrm{H}$, and $\mathrm{C}-\mathrm{O}$ bonds. The most stable adsorption configuration of the reaction intermediates is determined by using DFT. It has been demonstrated that $\mathrm{HCOOH}$, HCOO, mHCOO, cis- $\mathrm{COOH}$, trans- $\mathrm{COOH}, \mathrm{CO}, \mathrm{H}_{2} \mathrm{O}, \mathrm{OH}$ and $\mathrm{H}$ exhibit chemical adsorption, whereas cis- $\mathrm{HCOOH}$ and $\mathrm{CO}_{2}$ exhibit weak interactions with $\mathrm{Pd} / \mathrm{WC}(0001)$ surface. Furthermore, different reaction pathways of $\mathrm{HCOOH}$ decomposition are proposed to unveil the decomposition mechanism. The results reveal that $\mathrm{O}-\mathrm{H}$ bond cleavage exhibits the minimum energy barrier, whereas the bidentate $\mathrm{HCOO}$ is the main intermediate of $\mathrm{HCOOH}$ decomposition, which can be further converted into monodentate $\mathrm{HCOO}$. The energy barrier of $\mathrm{CO}_{2}$ generation from monodentate $\mathrm{HCOO}$ is $0.04 \mathrm{eV}$ lower than bidentate HCOO. In the case of $\mathrm{HCOO}, \mathrm{CO}_{2}$ is the main dissociation product, which determines the reaction rate. On the other hand, $\mathrm{CO}$ is the major dissociation product of cis- $\mathrm{COOH}$ and trans- $\mathrm{COOH}$ configurations. In addition, the direct generation of $\mathrm{CO}$ from $\mathrm{HCOOH}$ exhibits a relatively higher energy barrier. Furthermore, it has been demonstrated that the most favorable $\mathrm{HCOOH}$ decomposition route on $\mathrm{Pd} / \mathrm{WC}(0001)$ surface is $\mathrm{HCOOH} \rightarrow \mathrm{HCOO} \rightarrow \mathrm{CO}_{2}$, where the dehydrogenation of HCOO determines the rate of $\mathrm{CO}_{2}$ production.

The present study provides a detailed overview of the kinetics and mechanism of active intermediates and $\mathrm{HCOOH}$ decomposition on Pd/WC (0001) surface. Overall, CO formation occurs through the decomposition of cis- $\mathrm{COOH}$, trans- $\mathrm{COOH}$ and $\mathrm{HCO}$, whereas the $\mathrm{CO}_{2}$ formation happens due to the decomposition of HCOO. In general, $\mathrm{CO}_{2}$ is the main product of formic acid decomposition on the surface of the catalyst. These observations are consistent with the previously published reports about formic acid decomposition on $\operatorname{Pd}(111)$ surface [58], implying that the presence of WC, as monolayer Pd carrier, does not alter the catalytic behavior of Pd and significantly reduces the Pd utilization.

\section{References}

[1] K. J. Jeong, C. M. Miesse, J. H. Choi, J. Lee, J. Han, S. P. Yoon, S. W. Nam, T. H. Lim, T. G. Lee, J. Power Sources, 2007, 168, 119-125.

[2] X. W. Yu, P. G. Pickup, J. Power Sources, 2008, 182, 124-132.

[3] Q. Lv, Q. L. Meng, W. W. Liu, N. Sun, K. Jiang, L. P. Ma, Z. Q. Peng, W. B. Cai, C. P. Liu, J. J. Ge, L. M. Liu, W. Xing, J. Phys. Chem. C, 2018, 122, 2081-2088.

[4] J. W. Cho, S. Lee, S. P. Yoon, J. Han, S. W. Nam, K. Y. Lee, H. C. Ham, ACS Catal., 2017, 7, 2553-2562.

[5] W. H. Wang, T. He, X. H. Liu, W. N. He, H. J. Cong, Y. B. Shen, L. M. Yan, X. T. Zhang, J. P. Zhang, X. C. Zhou, ACS Appl. Mater. Interfaces, 2016, 8, 20839-20848.

[6] S. Lee, J. Cho, J. H. Jang, J. Han, S. P. Yoon, S. W. Nam, T. H. Lim, H. C. Ham, ACS Catal., 2016, 6, 134-142.

[7] W. Y. Yu, G. M. Mullen, D. W. Flaherty, C. B. Mullins, J. Am. Chem. Soc., 2014, 136, 11070-11078.

[8] J. Cho, S. Lee, J. Han, S. P. Yoon, S. W. Nam, S. H. Choi, K. Y. Lee, H. C. Ham, J. Phys. Chem. C, 2014, 118, 22553-22560.

[9] K. Mori, M. Dojo, H. Yamashita, ACS Catal., 2013, 3, 1114-1119.

[10] Z. F. Wu, Z. Q. Jiang, Y. K. Jin, F. Xiong, G. H. Sun, W. X. Huang, Chin. J. Catal., 2016, 37, 1738-1746.

[11] R. Sang, P. Kucmierczyk, K. W. Dong, R. Franke, H. Neumann, R. Jackstell, M. Beller, J. Am. Chem. Soc., 2018, 140, 5217-5223.

[12] W. F. Wang, Y. F. Zhang, J. Q. Li, K. N. Ding, Chin. J. Catal., 2004, 25, 129-132.

[13] W. Z. Yu, Z. L. Xin, W. Zhang, Y. A. Xie, J. Wang, S. Niu, Y. F. Wu, L. D. Shao, Chem. Phys. Lett., 2017, 686, 155-160.

[14] X. B. Li, Y. Y. Zhu, G. Chen, G. H. Yang, Z. Wu, B. Sunden, Int. J. Hydrogen Energy, 2017, 42, 24726-24736.

[15] R. G. Zhang, M. Yang, M. Peng, L. X. Ling, B. J. Wang, Appl. Surf. Sci., 2019, 465, 730-739.

[16] E. Cazares-Avila, E. J. Ruiz-Ruiz, A. Hernandez-Ramirez, F. J. Ro- 


\section{Graphical Abstract}

Chin. J. Catal., 2020, 41: 415-425 doi: S1872-2067(19)63463-7

Unveiling the decomposition mechanism of formic acid on Pd/WC(0001) surface by using density function theory

Jinhua Zhang, Yuanbin She*

Zhejiang University of Technology; Chizhou University

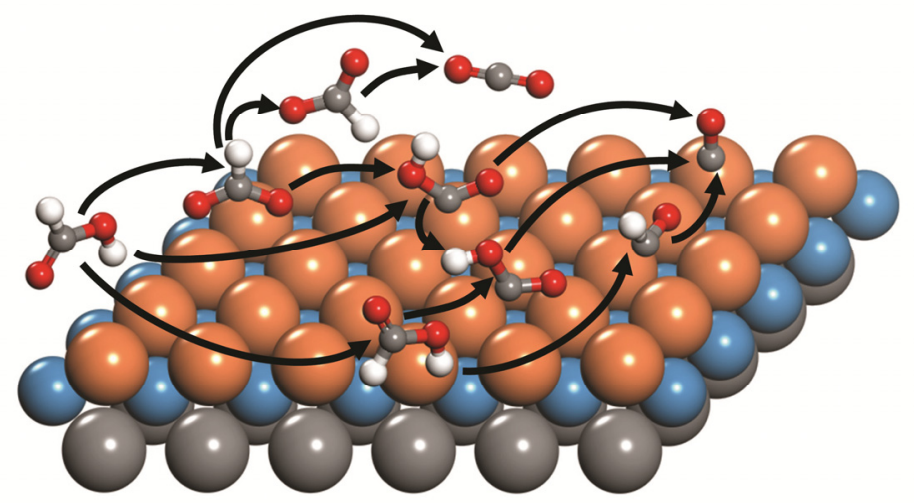

The network of reaction steps for $\mathrm{HCOOH}$ decomposition on $\mathrm{Pd} / \mathrm{WC}(0001)$ surface are presented. Red, orange, blue, gray and white balls represent $\mathrm{O}$ atoms, $\mathrm{Pd}$ atoms, $\mathrm{W}$ atoms, $\mathrm{C}$ atoms and $\mathrm{H}$ atoms, respectively.

driguez-Varela, M. D. Morales-Acosta, D. Morales-Acosta, Int. J. Hydrogen Energy, 2017, 42, 30349-30358.

[17] J. Scaranto, M. Mavrikakis, Surf. Sci., 2016, 650, 111-120.

[18] J. Y. Wang, H. X. Zhang, K. Jiang, W. B. Cai, J. Am. Chem. Soc., 2011, 133, 14876-14879.

[19] D. W. Yuan, Y. Zhang, Appl. Surf. Sci., 2018, 462, 649-658.

[20] W. Gao, J. A. Keith, J. Anton, T. Jacob, J. Am. Chem. Soc., 2010, 132, 18377-18385

[21] Y. Y. Wang, P. Liu, D. J. Zhang, C. B. Liu, Int. J. Hydrogen Energy, 2016, 41, 7342-7351.

[22] L. H. Ou, J. X. Chen, Y. D. Chen, J. L. Jin, J. Phys. Chem. C, 2018, 122, 24871-24884.

[23] W. Gao, J. A. Keith, J. Anton, T. Jacob, J. Am. Chem. Soc., 2010, 132, 18377-18385.

[24] Y. F. Wang, K. Li, G. C. Wang, Appl. Surf. Sci., 2018, 436, 631-638.

[25] Y. Y. Wang, Y. Y. Qi, D. J. Zhang, C. B. Liu, J. Phys. Chem. C, 2014, 118, 2067-2076.

[26] J. W. Zhang, M. S. Chen, H. Q. Li, Y. J. Li, J. Y. Ye, Z. M. Cao, M. L. Fang, Q. Kuang, J. Zheng, Z. X. Xie, Nano Energy, 2018, 44, 127-134.

[27] K. Tedsree, T. Li, S. Jones, C. W. A. Chan, K. M. K. Yu, P. A. J. Bagot, E. A. Marquis, G. D. W. Smith, S. C. E. Tsang, Nat. Nanotechnol., 2011, 6, 302-307.

[28] S. Uhm, H. J. Lee, Y. Kwon, J. Lee, Angew. Chem. Int. Ed., 2008, 47, 10163-10166.

[29] J. Y. Wang, Y. Y. Kang, H. Yang, W. B. Cai, J. Phys. Chem. C, 2009, 113, 8366-8372.

[30] H. X. Zhang, C. Wang, J. Y. Wang, J. J. Zhai, W. B. Cai, J. Phys. Chem. C, 2010, 114, 6446-6451.

[31] R. B. Levy, M. Boudart, Science, 1973, 181, 547-549.

[32] N. R. Elezovic, P. Zabinski, P. Ercius, M. Wytrwal, V. R. Radmilovic, U. C. Lacnjevac, N. V. Krstajic, Electrochim. Acta, 2017, 247, 674-684.

[33] Q. Zhang, Z. J. Mellinger, Z. Jiang, X. Chen, B. Wang, B. Y. Tian, Z. X.
Liang, J. G. G. Chen, J. Electrochem. Soc., 2018, 165, J3031-J3038.

[34] Z. Yan, Y. Gu, W. Wei, Z. Jiang, J. Xie, P. K. Shen, Fuel Cells, 2015, 15, 256-261.

[35] J. S. Moon, Y. W. Lee, S. B. Han, K. W. Park, Int. J. Hydrogen Energy, 2014, 39, 7798-7804.

[36] Y. X. Zhang, Z. X. Yang, J. Alloys Compd., 2019, 775, 330-334.

[37] D. V. Esposito, J. G. G. Chen, Energy Environ. Sci., 2011, 4, 3900-3912.

[38] Z. J. Mellinger, T. G. Kelly, J. G. G. Chen, ACS Catal., 2012, 2, 751-758.

[39] N. R. Elezovic, P. Zabinski, P. Ercius, M. Wytrwal, V. R. Radmilovic, U. Č. Lačnjevac, N. V. Krstajic, Electrochim. Acta, 2017, 247, 674-684.

[40] X. L. Zhang, Z. S. Lu, Z. X. Yang, J. Power Sources, 2016, 321, 163-173.

[41] C. Y. He, J. Z. Tao, Y. B. Ke, Y. F. Qiu, $R S C A d v ., 2015,5$, 66695-66703.

[42] M. Yin, Q. F. Li, J. O. Jensen, Y. J. Huang, L. N. Cleemann, N. J. Bjerrum, W. Xing, J. Power Sources, 2012, 219, 106-111.

[43] S. D. Guo, X. C. Hu, J. G. Yang, H. Chen, Y. Zhou, J. Fuel Chem. Technol., 2016, 44, 698-702.

[44] S. J. Li, X. Zhou, W. Q. Tian, J. Phys. Chem. A, 2012, 116, 11745-11752.

[45] B. Delley, J. Chem. Phys., 2000, 113, 7756-7764.

[46] J. P. Perdew, K. Burke, M. Ernzerhof, Phys. Rev. Lett., 1996, 77, 3865-3868.

[47] Z. Fang, Y. Zhao, H. Y. Wang, J. F. Wang, S. J. Zhu, Y. Jia, J. Y. Cho, S. K. Guan, Appl. Surf. Sci., 2019, 470, 893-898.

[48] K. Palotás, I. Bakó, L. Bugyi, Appl. Surf. Sci., 2016, 389, 1094-1103.

[49] C. Q. Hu, S. W. Ting, K. Y. Chan, W. Huang, Int. J. Hydrogen Energy, 2012, 37, 15956-15965.

[50] S. D. Zhou, C. Qian, X. Z. Chen, Catal. Lett., 2011, 141, 726-734.

[51] T. A. Halgren, W. N. Lipscomb, Chem. Phys. Lett., 1977, 49, 
225-232.

[52] X. L. Zhang, Z. X. Yang, R. Q. Wu, Nanoscale, 2018, 10, 4753-4760.

[53] Y. F. Li, Y. M. Gao, B. Xiao, T. Min, Z. J. Fan, S. Q. Ma, D. W. Yi, Comp. Mater. Sci., 2011, 50, 939-948.

[54] D. W. Yuan, J. Y. Li, L. H. Liu, Catal. Lett., 2016, 146, 2348-2356.
[55] R. B. Jiang, W. Y. Guo, M. Li, X. Q. Lu, J. Y. Yuan, H. H. Shan, Phys. Chem. Chem. Phys., 2010, 12, 7794-7803.

[56] J. Scaranto, M. Mavrikakis, Surf. Sci., 2016, 648, 201-211.

[57] R. G. Zhang, H. Y. Liu, B. J. Wang, L. X. Ling, J. Phys. Chem. C, 2012, $116,22266-22280$.

\title{
DFT法研究HCOOH在Pd/WC(0001)上的分解机理
}

\author{
张金花, ${ }^{\mathrm{a}, \mathrm{b}}$, 余远斌, ${ }^{\mathrm{a}}$ * \\ $a^{a}$ 浙江工业大学化学工程学院, 浙江杭州 310014

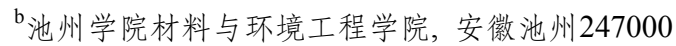

\begin{abstract}
摘要: 作为便携式电子设备的动力源, 直接甲酸燃料电池(DFAFC)具有燃料跨界范围小、电动势大、甲酸无毒、低温下功 率密度大等优点, 因而引起了人们的极大兴趣. DFAFC商业化的主要挑战之一是阳极电催化剂材料的高成本和低CO耐受 性. 阳极通常需要高负载的贵金属电催化剂(Pt或Pd)氧化甲酸 $(\mathrm{HCOOH})$ 以获得所需的电能. 完全电氧化甲酸在Pt和Pd表面 上会产生强吸附的 $\mathrm{CO}$, 从而降低了Pt或Pd催化剂的活性. Pt和Pd储量少且价格昂贵, 减少Pt和Pd含量且保持催化性能的燃 料电池催化剂一直是研究者的奋斗目标.

本文用周期性密度泛函理论(DFT)系统地研究了WC负载的单分子层Pd (Pd/WC $(0001)$ )催化剂对甲酸的分解机理, 这 可为所需的反应路径设计、篮选催化剂提供指导.

Trans- $\mathrm{HCOOH}$ 通过 C-H, O-H, C-O键的活化发生分解. 关于吸附, 确定了可能反应中间体的最稳定吸附构型. trans- $\mathrm{HCOOH}, \mathrm{HCOO}, \mathrm{mHCOO}$, cis- $\mathrm{COOH}$, trans- $\mathrm{COOH}, \mathrm{CO}, \mathrm{H}_{2} \mathrm{O}, \mathrm{OH}$ 和 $\mathrm{H}$ 的吸附过程是化学吸附, 而 cis- $\mathrm{HCOOH}$ 和 $\mathrm{CO}_{2}$ 与 $\mathrm{Pd} / \mathrm{WC}(0001)$ 表面的相互作用较弱, 是物理吸附. 此外, 提出了 trans-HCOOH分解的不同途径来探索分解机理. trans-HCOOH中 $\mathrm{O}-\mathrm{H}, \mathrm{C}-\mathrm{H}$ 和C-O键的活化能垒分别为 $0.61,0.77$ 和 $1.05 \mathrm{eV}, \mathrm{O}-\mathrm{H}$ 键断裂的能垒最小, 则 trans-HCOOH优先通 过 $\mathrm{O}-\mathrm{H}$ 键断裂生成 $\mathrm{HCOO}$. 双齿 $\mathrm{HCOO}$ 是 $\mathrm{HCOOH}$ 分解的主要中间体, 它可以转变为单齿 $\mathrm{HCOO}$, 这条路线生成 $\mathrm{CO}_{2}$ 的能垒 比双齿 $\mathrm{HCOO}$ 的低 $0.04 \mathrm{eV} . \mathrm{CO}_{2}$ 是 $\mathrm{HCOO}$ 主要解离产物, 这一步是总反应的决速步骤. 对于cis- $\mathrm{COOH}$ 和 trans- $\mathrm{COOH}, \mathrm{CO}$ 是 其主要解离产物. 此外, trans- $\mathrm{HCOOH}$ 也能直接生成 $\mathrm{CO}$, 但克服的能垒较大. 在 $\mathrm{Pd} / \mathrm{WC}(0001)$ 表面上分解trans-HCOOH的最 有利途径是 $\mathrm{HCOOH} \rightarrow \mathrm{HCOO} \rightarrow \mathrm{CO}_{2}$, 其中 $\mathrm{HCOO}$ 脱氢形成 $\mathrm{CO}_{2}$ 的步骤是速率决定步骤.

本文提供了 $\mathrm{HCOOH}$ 在 $\mathrm{Pd} / \mathrm{WC}(0001)$ 表面上分解的活性中间体、能垒和机理的推测, $\mathrm{CO}$ 形成主要是通过cis- $\mathrm{COOH}$ 、 trans- $\mathrm{COOH}$ 及 $\mathrm{HCO}$ 的分解, $\mathrm{CO}_{2}$ 的形成主要是通过 $\mathrm{HCOO}$ 的分解, $\mathrm{CO}_{2}$ 占主导. 该结论与 $\mathrm{Pd}(111)$ 面上甲酸分解结果一致, 说 明WC作为Pd载体没有改变Pd对甲酸的催化性能, 但降低了Pd的使用量.

综上, 本文阐明了 WC 负载单分子层Pd催化剂上甲酸催化分解机理, 得出甲酸分解的最佳反应路径, 为直接甲酸燃料电 池设计低贵金属含量、高活性的负载型Pd催化剂提供了理论指导; 可用于预测不同载体负载Pd催化剂的性能, 大大减少实 验成本, 以验证提出的实验假设.
\end{abstract}

关键词: 密度泛函理论; 甲酸; 直接甲酸燃料电池; WC(0001)负载单分子层Pd; 分解机理

收稿日期: 2019-06-18. 接受日期: 2019-07-26. 出版日期: 2020-03-05.

*通讯联系人. 电话/传真: (0571)88320533; 电子信箱: sheyb@zjut.edu.cn

基金来源: 国家自然科学基金(21776259); 微纳粉体与先进能源材料安徽普通高校重点实验室(池州学院).

本文的电子版全文由Elsevier出版社在ScienceDirect上出版(http://www.sciencedirect.com/science/journal/18722067). 